\title{
TOWARDS REDUCING CANCER DEATH: AN EXPLORATORY STUDY OF PHYSICIANS KNOWLEDGE ON CANCER BASIC FACTS.
}

\author{
${ }^{\star}$ E. P. Gharoro, *M. C. Ezeanochie, *E. J. Enabudoso. \\ *Department of Obstetrics and Gynaecology, University of Benin Teaching Hospital, \\ Benin City, Nigeria.
}

\section{Correspondence:}

Dr. E. P. Gharoro

Department of Obstetrics and Gynaecology,

University of Benin Teaching Hospital,

P.M.B 1111 Ugbowo

Benin City, Edo State

Nigeria.

E-mail: gharoro@hotmail.com; gharoro@uniben.edu

\section{ABSTRACT}

Objective: To explore the knowledge of basic facts on common female cancers amongst Physicians in active practice.

Materials and Methods: A descriptive study among 160 doctors working in a Nigerian Teaching Hospital.

Results: Majority of the physicians surveyed $(86.2 \%)$ were in full time academic practice with $13.8 \%$ in combined academic and private practice. The experience (years in practice) of the Physicians varied from 1-22 years, with a majority $(57.9 \%)$ in category A (1-5 years ), while $40.3 \%$ were in category $D$ (>15 years).

A large proportion of the Physicians had poor knowledge on basic cancer facts with regards to the prevalence $(47.2 \%)$, mortality rate $(54.1 \%)$, available screening tests $(65.4 \%)$, and association between HPV and cancers of the anogenital region (56.6\%). The type of practice did not significantly influence Physicians knowledge on basic cancer facts ( $P$ values $>0.05$ ) More Physicians in full academic practice had good knowledge about human papilloma virus compared to those in combined practice $(23.3 \%$ vs. $5 \%$; fulltime academics vs. combine practice). There was no significant difference in the knowledge of the Physicians on the prevalence, available screening tests and mortality rate of the cancers based on their experience $(P$ values $>0.05)$

Conclusion: Physicians in active practice have poor knowledge of basic cancer facts irrespective of their number of years in practice. These portend serious setback for health education, policy formulation on prevention and reduction of Cancer related morbidity and mortality.

Keywords: Cancer, Human papilloma Virus (HPV), Knowledge, counselling

\section{INTRODUCTION}

Physicians in practice invariably are involved with counselling and or screening patients for cancer in the community. Their basic knowledge on the general facts and risk factors for cancer influences the participation of patients in gynaecological cancer screening, service uptake and compliance with treatment regimen ${ }^{1,2}$. As a matter of fact, the knowledge of women on the risk factors and available screening modalities for gynaecological cancer are mainly obtained through contact with and information from their Physicians ${ }^{2-5}$. 
Cancer control and reduction of death from cancer in the community is influenced by participation rates in cancer screening programs. The knowledge of patients may influence their participation and compliance with these programs. Therefore, programs designed to reduce cancer related morbidity and mortality death will depend on the accuracy of the knowledge passed on by Physicians in practice to their patients. Published data abound on the relationship between the human papilloma virus (HPV) and neoplastic lesions of the anogenital tract ${ }^{6-8}$. It is now firmly established that HPV is a causal factor in many anogenital cancers ${ }^{9,10}$.

Most study efforts have been concentrated on the role of patients' knowledge and availability of information to patients, on screening programmes and service uptake ${ }^{11,12}$. Physicians should not only treat diseases but offer strategies to prevent them. This exploratory study was undertaken to evaluate the baseline knowledge of cancer facts amongst Physicians, especially those in active practice, on basic facts on common female cancers. The findings from this study will contribute towards the development of policies and strategies to reduce the morbidity and mortality from female cancers.

\section{MATERIALS AND METHODS}

In the months of April- June 2007, we surveyed 160 Doctors at the University of Benin Teaching Hospital, Benin City with a structured questionnaire. The questionnaire contained sections on personal data, years of practice (experience), specialty and type of practice (full time academic, private practice or combined).

The other sections contained questions to test the knowledge of the Physicians on basic facts on six common female cancers. The respondents were presented 3 tables with two columns each; the first column had six common female cancers randomly listed, in the blank second column, the respondent were requested to arrange in order of decreasing magnitude the Prevalence, Mortality rates, and the order in which they would arrange for screening tests. In addition, there was a table to evaluate Respondents knowledge on association between Human Papiloma virus (HPV) and anogenital cancers; a separate table required the Physicians to list six available screening tests for cancers in contemporary practice.

\section{Data management}

159 questionnaires were returned sufficiently filled for analysis. The answers given by the respondents in Items $7-11$ on the questionnaire were scored and graded as Good (if at least 5 of the 6 items were correctly completed), Average (if 3 or 4 correct answer) or Poor Knowledge (less than 4 correct answers). The years in practice (Experience) was stratified into four categories: A (1-5 years), B (6-10 years), $C$ (11-15 years), and $D$ (>15years). The data generated was analyzed using SPSS statistical software, version 15 (SPSS, Chicago, IL, USA). Analysis was done to compare mean values, Chi-square tests and the Fisher's exact test where appropriate at $95 \%$ confidence level with a $P$ value of $<0.05$ as significant.

\section{RESULTS}

The mean age of the respondents was 30.95 years \pm 4.4 , range 24 to 51 years. There were 44 female doctors compared to 115 male doctors. There was a significant difference in the mean age of both sexes (Female vs. Male: 28.6 vs. 31.9 years, $P<0.001)$. The experience (years in practice) of the Physicians varied from 1-22 years, mean $4.4 \pm 3.9$ years. Majority of the 
Physicians 92 (57.9\%) were in category A (1-5 years) experience, 1 $(0.6 \%)$ in category $B(6-10$ years), 2 $(1.3 \%)$ in category $C(11-15$ years $)$ while $64(40.3 \%)$ were in category D (>15 years). Physicians in full time academics were $137(86.2 \%)$, while 22 $(13.8 \%)$ were in combined academics and private practice. There were no full-time Private Practitioners in the study.

Basic facts

Majority of the physicians (47.2\%) had poor knowledge about the prevalence, mortality rates and available screening tests for the common female cancers $(47.2 \%, \quad 54.1 \%$ and $65.4 \%$ respectively) as shown in Table I.

Table I: PHYSICIANS' KNOWLEDGE ABOUT THE PREVALENCE, MORTALITY RATE, AND AVAILABLE SCREENING TESTS FOR THE COMMON FEMALE CANCERS

\begin{tabular}{llll|}
$\begin{array}{l}\text { Physicians' knowledge } \\
\text { on }\end{array}$ & $\begin{array}{l}\text { Prevalence rate } \\
\text { Number (\%) }\end{array}$ & $\begin{array}{l}\text { Mortality rate } \\
\text { Number (\%) }\end{array}$ & $\begin{array}{l}\text { Screening tests } \\
\text { Number }(\%)\end{array}$ \\
\hline Poor & $75(47.2)$ & $86(54.1)$ & $104(65.4)$ \\
\hline Average & $49(30.8)$ & $54(34.0)$ & $35(22.0)$ \\
Good & $35(22.0)$ & $19(11.9)$ & $20(12.6)$ \\
\hline Total & $\mathbf{1 5 9}(\mathbf{1 0 0 . 0 )}$ & $\mathbf{1 5 9}(\mathbf{1 0 0 . 0 )}$ & $\mathbf{1 5 9}(\mathbf{1 0 0 . 0 )}$ \\
\hline
\end{tabular}

Type of practice and Knowledge on Basic cancer facts

Good knowledge about the available screening tests was significantly more among physicians in full time academic practice than those in combined practice in Table II $(23.3 \%$ vs. $5 \%, \mathrm{P}=0.025)$. The Physicians knowledge on the prevalence, mortality rate of the different cancers and the relationship between HPV and anogenital cancers was not significantly influenced by their type of practice ( $P$ values $>0.05$ ).
Experience and Knowledge on Basic cancer facts

There was no significant difference in the knowledge of the prevalence, mortality rates and available screening tests when compared to the years of experience of the physicians. However, further analysis showed that Physicians in category A experience significantly had more good knowledge about association between HPV and cancers of the anogenital region compared to category $\mathrm{D}$ experience (20.8\% vs. $5.7 \%, P=0.005$. 
Table II: PHYSICIANS TYPE OF PRACTICE AND THEIR KNOWLEDGE ON BASIC CANCER FACTS

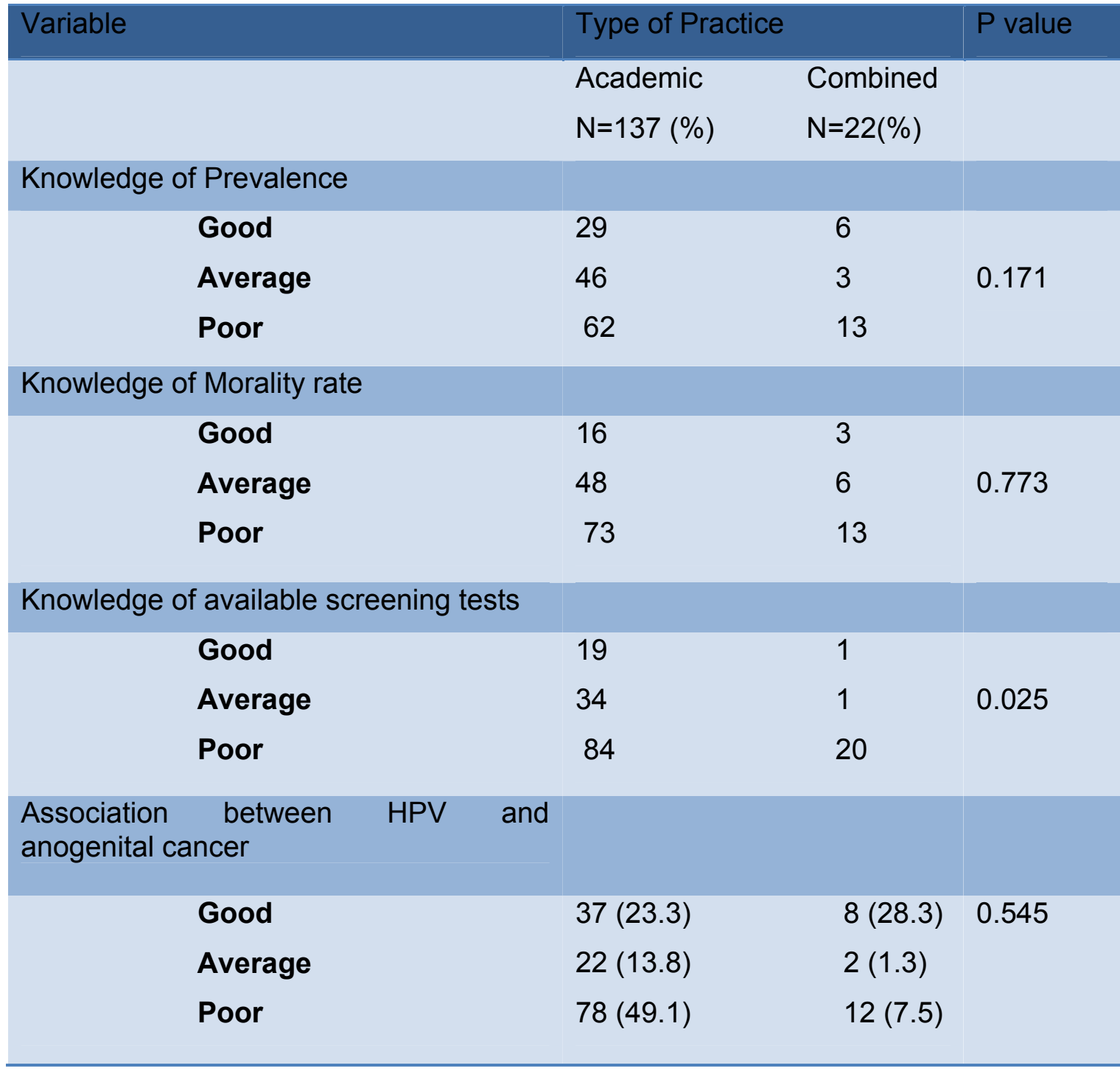

\section{DISCUSSION}

This study shows that the knowledge of Physicians in active practice on basic facts about common female cancers was poor. This trend may partly explain the low levels of awareness and poor service uptake by patients of cancer prevention programs observed by other reports. $^{4,11,12}$ This is particularly important because Physicians are important avenue for health information dissemination among patients especially in developing countries and if their knowledge base is not adequate, it raises important public health concerns. Ameliorating this lack of accurate information may influence the perception of cancer and result in higher participation rates in cancer screening programmes especially in an environment where largely preventable cancer death, like cervical cancer, is still high.,12 The need for continuous medical education and re-training is therefore necessary. Infection with the human papilloma virus (HPV) is the most common sexually transmitted disease and is now firmly established as a necessary causal factor in cervical carcinogenesis and other anogenital 
cancers in both male and female ${ }^{8-10}$ The importance attached to the oncogenic effects of HPV has led to the development of vaccines against HPV. ${ }^{13-15}$ This presents an important opportunity for reducing the HPV related genital cancer especially in our environment with a largely nonexistent organised screening program for genital tract cancers., ${ }^{4,12}$ However, the success or failure of such a program in reducing HPV related genital tract cancer burden may depend largely on the availability and management of accurate information by health professionals including Physicians. This study revealed that less than a third of our Clinicians are aware of the oncogenic property of the HPV virus. Knowledge was significantly better for the young physician within five years of graduation compared to the group who were at least fifteen years post graduation. This trend may reflect the information acquired by the younger Physicians during their basic medical training in an era where HPV and tumorigenesis was topical compared to the older Physicians.

The type of practice, full time academic or combined practice, did not however significantly influence the knowledge of the Physicians. This may be due to the small number of Physicians in these groups. Also, although the study population was of a limited size and they were from a single institution, the findings from this work is very relevant as a preliminary survey considering the overall poor knowledge base of the Physicians surveyed. Larger community based studies are necessary to provide more insight into the knowledge base of Physicians in active practice and factors that determinant it.

\section{CONCLUSION}

Conclusively, the poor knowledge base of the physicians raises important public health questions especially if programs designed to reduce morbidity and mortality from genital tract cancers are to succeed. There is a need therefore to urgently start the much proposed periodic continuous medical education program for practicing physicians in Nigeria before renewal of Professional Practice Licence.

\section{REFERENCES}

1. Baay MF, Verhoeven V, Peremans L, Avonts D, Vermorken JB. General practitioners' perception of risk factors for cervical cancer development: consequences for patient education. Patient Educ Couns. 2006; 62(2):277-81.

2. Tiro JA, Meissner HI, Kobrin S, Chollette V. What do women in the U.S. know about human papillomavirus and cervical cancer? Cancer Epidemiol Biomarkers Prev. 2007; 16(2):28894.

3. Bowman JA, Redman S, Reid AL, Sanson-Fisher RW. General practitioners and the provision of Papanicolaou smear-tests: current practice, knowledge and attitudes. Med J Aust. 1990; 152(4):178-83.

4. Gharoro EP, Ikeanyi EN. An Appraisal of the Level of Awareness and Utilization of Pap Smear as a Cervical Cancer Screening Test amongst Female Health Workers in a tertiary health institution. Int J Gynecol Cancer. 2006; 16(3):1063-8.

5. Ackermann S, Renner SP, Fasching PA, Poehls U, Bender 
HG, Beckmann MW. Awareness of general and personal risk factors for uterine cancer among healthy women. Eur J Cancer Prev. 2005; 14(6):519-24.

6. Partridge JM, Hughes JP, Feng $Q$, Winer RL, Weaver BA, Xi LF, Stern ME, Lee SK, O'Reilly SF, Hawes SE, Kiviat NB, Koutsky LA. Genital human papillomavirus infection in men: incidence and risk factors in a cohort of university students. J Infect Dis. 2007; 196(8):1128-36.

7. Castellsagué $X$, Bosch FX, Muñoz $\mathrm{N}$, Meijer CJ, Shah KV, de Sanjose $\mathrm{S}$, Eluf-Neto J, Ngelangel CA, Chichareon S, Smith JS, Herrero $\mathrm{R}$, Moreno V, Franceschi S; International Agency for Research on Cancer Multicenter Cervical Cancer Study Group. Male circumcision, penile human papillomavirus infection, and cervical cancer in female partners. N Engl J Med. 2002; 346(15):110512.

8. Nielson CM, Harris RB, Dunne EF, Abrahamsen $M$, Papenfuss MR, Flores R, Markowitz LE, Giuliano AR. Risk factors for anogenital human papilloma virus infection in men. J Infect Dis. 2007; 196(8):1137-45.

9. Bleeker MC, Heideman DA, Snijders PJ, Horenblas S, Dillner J, Meijer CJ. Penile cancer: epidemiology, pathogenesis and prevention. World J Urol. 2008 Jul 8.

10. Fletcher HM, Hanchard B. Poverty eradication and decreased human papilloma virus related cancer of the penis and vulva in Jamaica. $J$ Obstet Gynaecol. 2008; 28(3):3335.

11. Idestrom M, Milsom I, AnderssonEllstrom A. Knowledge and attitudes about the Pap-smear screening program: a populationbased study of women aged 20-59 years. Acta Obstet Gynecol Scand 2002; 81:962-7.

12. Obi SN, Ozumba BC, Nwokocha AR, Waboso PA. Participation in highly subsidized cervical cancer screening by women in Enugu, South-east Nigeria. J Obstet Gynaecol. 2007; 27(3):305-7.

13. Di Giuseppe G, Abbate R, Liguori G, Albano L, Angelillo IF.. Human papillomavirus and vaccination: knowledge, attitudes, and behavioural intention in adolescents and young women in Italy. Br J Cancer. 2008; 99(2):2259.

14. Cutts FT, Franceschi S, Goldie S, Castellsague $X$, de Sanjose $S$, Garnett G, Edmunds WJ, Claeys P, Goldenthal KL, Harper DM, Markowitz L. Human papillomavirus and HPV vaccines: a review. Bull World Health Organ. 2007; 85(9):719-26.

15. Vonka V, Hamsíková E. Vaccines against human papillomaviruses--a major breakthrough in cancer prevention. Cent Eur J Public Health. 2007; 15(4):131-9. 